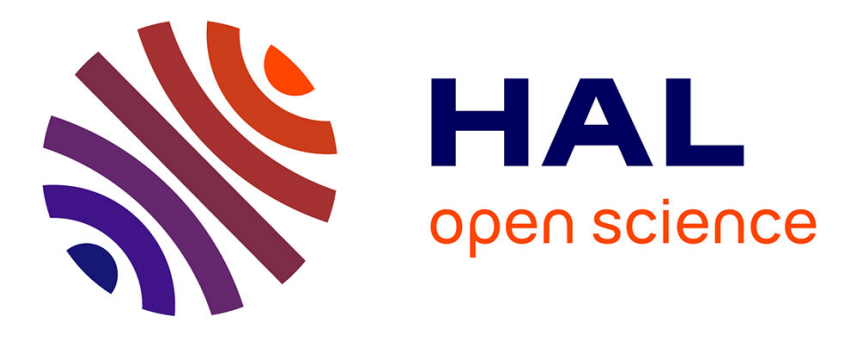

\title{
Steel Thixoforging: Heat Exchange Impact on the Mechanical and Metallurgical Features of Thixoforged Samples
}

Eric Becker, Pierre Cezard, Régis Bigot, Laurent Langlois, Véronique Favier, Jean-Christophe Pierret

\section{To cite this version:}

Eric Becker, Pierre Cezard, Régis Bigot, Laurent Langlois, Véronique Favier, et al.. Steel Thixoforging: Heat Exchange Impact on the Mechanical and Metallurgical Features of Thixoforged Samples. Solid State Phenomena, 2008, 141-143, pp.701-706. 10.4028/www.scientific.net/SSP.141-143.701 . hal01090341

\section{HAL Id: hal-01090341 https://hal.science/hal-01090341}

Submitted on 3 Dec 2014

HAL is a multi-disciplinary open access archive for the deposit and dissemination of scientific research documents, whether they are published or not. The documents may come from teaching and research institutions in France or abroad, or from public or private research centers.
L'archive ouverte pluridisciplinaire HAL, est destinée au dépôt et à la diffusion de documents scientifiques de niveau recherche, publiés ou non, émanant des établissements d'enseignement et de recherche français ou étrangers, des laboratoires publics ou privés. 


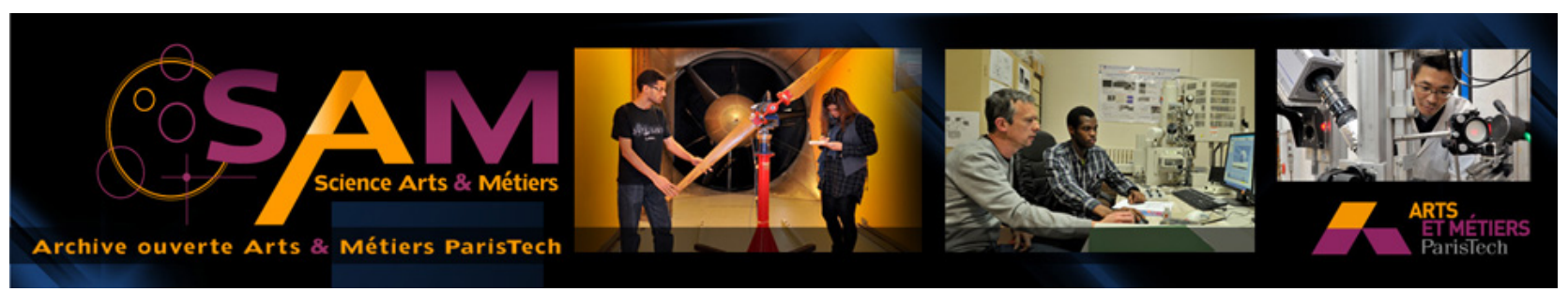

\section{Science Arts \& Métiers (SAM)}

is an open access repository that collects the work of Arts et Métiers ParisTech researchers and makes it freely available over the web where possible.

This is an author-deposited version published in: http://sam.ensam.eu

Handle ID: .http://hdl.handle.net/10985/9047

\section{To cite this version :}

Eric BECKER, Pierre CEZARD, Régis BIGOT, Laurent LANGLOIS, Véronique FAVIER, JeanChristophe PIERRET - Steel Thixoforging: Heat Exchange Impact on the Mechanical and Metallurgical Features of Thixoforged Samples - Solid State Phenomena - Vol. 141-143, p.701$706-2008$ 


\title{
Steel Thixoforging: Heat Exchange Impact on the Mechanical and Metallurgical Features of Thixoforged Samples
}

\author{
Eric Becker ${ }^{1, \mathrm{a}}$, Pierre Cezard ${ }^{3, \mathrm{~b}}$, Régis Bigot ${ }^{1, \mathrm{c}}$, Laurent Langlois $^{1, \mathrm{~d}}$, \\ Véronique Favier ${ }^{2, e}$ and Jean Christophe Pierret ${ }^{4, f}$ \\ ${ }^{1}$ Laboratoire de Génie Industriel et de Production Mécanique (LGIPM) -ENSAM - 4, rue Augustin \\ Fresnel - F57070 Metz Technopôle - France \\ ${ }^{2}$ LIM UMR 8006- ENSAM - 151, boulevard de l'Hôpital - F75013 Paris - France \\ ${ }^{3}$ ASCOMETAL CREAS - avenue France - F57300 Hagondange - France \\ ${ }^{4}$ ULG - PiMW (B56), University of Liège Boulevard de Colonster, 4 - B4000 Liège - Belgique \\ aeric.becker@metz.ensam.fr, ${ }^{b}$ p.cezard@ascometal.lucchini.com, ${ }^{c}$ regis.bigot@metz.ensam.fr, \\ dlaurent.langlois@metz.ensam.fr, ${ }^{\mathrm{d}}$ veronique.favier@metz.ensam.fr, jic.pierret@ulg.ac.be
}

Keywords: thermal exchanges, mechanical behaviour, microstructure, steel thixoforging, semisolid.

\begin{abstract}
Steel thixoforging process combines the advantages of performing parts having highly complex shapes and good mechanical properties. These advantages result from the shear thinning flow behaviour of semi-solids due to microstructure changes during the material deformation. Many parameters such as steel grade, raw speed, slug temperature, tool temperature influence the steel thixoforging process. In this work, we are interested in analysing the influence of thermal conditions as well as ram speed on the flow behaviour and the microstructure of the final parts. To do so, thixo-extrusion tests on a high speed hydraulic press were performed on C38 steels using different ram speeds and different temperatures for the tools. The temperature is measured in the die close to the tool-material interface during the whole process. Correlations between the temperature measurements, the flow profile and the microstructure are discussed. Using the Finite Element code Forge2005, these thixo-extrusion tests are simulated. Using an inverse method, some parameters used in the thermal exchange modelling are identified by successive comparisons between calculated and measured temperatures within the die.
\end{abstract}

\section{INTRODUCTION}

The moulding using the properties of fluidity of molten metal alloys makes it possible to obtain parts with complex shapes in only one step. These parts contain unwanted porosities and consequently present weak mechanical properties. On the contrary, forging provides parts with high mechanical characteristics but can require several steps to obtain the final part. Thixoforming and rheoforming are two forming processes lately developed. They enable the forging of parts with complex shapes and give high mechanical properties $[1,2]$. The aim is to get a mix of casting and forging strong points. Both thixoforging and rheoforging are based on the semi-solid state, the first using the melting of the metal, the second one using the solidification of the melted steel [3, 4]. Former studies show the impact of heat exchange within the processes of thixoforging $[5,6]$.

This document shows the progress of studies dealing with the forming of C38 steel by thixoforging and particularly impact of heat exchanges. The first part deals with steel thixoforging specificities and parameters affecting the forming process. The second part shows the analysis of the thermal exchange impact on the flow during the forming and on different aspects of the final part. 


\section{STEEL THIXOFORGING}

The difficulty of steel forming is mainly due the high level of temperature $\left(1400^{\circ} \mathrm{C}\right)$ and then to the die design. Studies developed dealt with the modelling of semi-solid steel behaviour with an original micro-macro approach [4, 7, 8].

Studies about the die design and the semi-solid state of slug are shown. Results about impact of some key parameters on thixoforging are then developed.

\section{Dies}

Direct extrusion test is used in order to identify key parameters concerning the flow of semisolid steel. It consists in a diameter reduction from $40 \mathrm{~mm}$ to $12 \mathrm{~mm}$. (figure 1).

Dies are either at room temperature or heated at $400^{\circ} \mathrm{C}$ with an induction heater integrated into the tool, in order to control the tests conditions and to avoid high thermal losses.

Some tools used at room temperature are equipped with thermocouples; the position of those in the tools is illustrated below (figure 2).

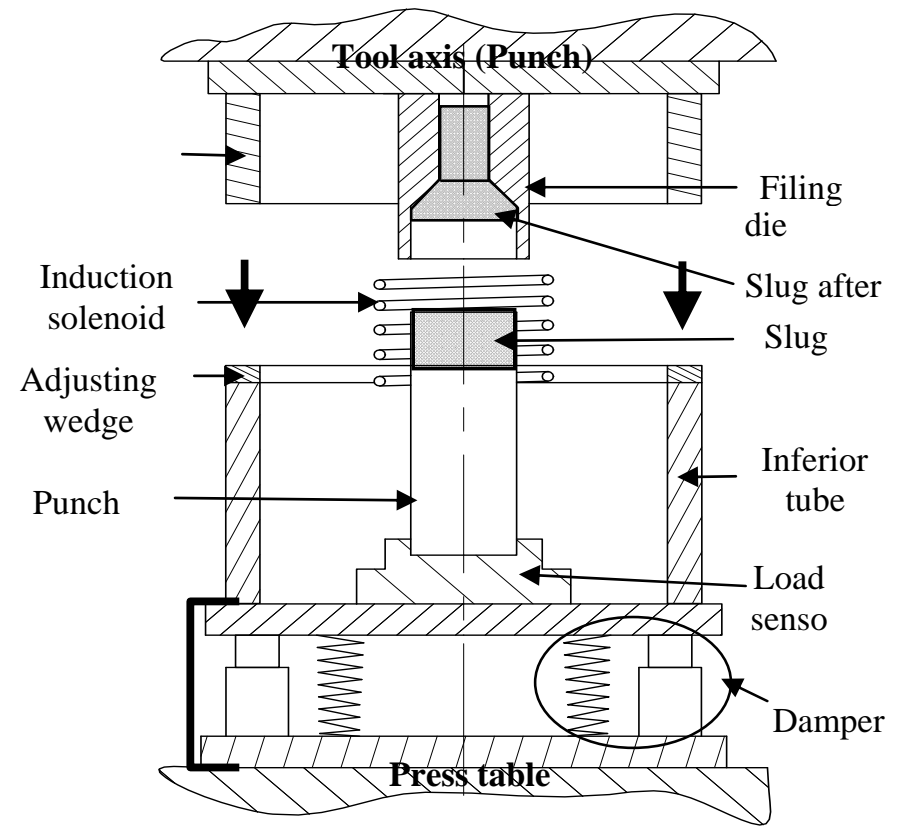

Fig.1. Complete extrusion device mounted on the press

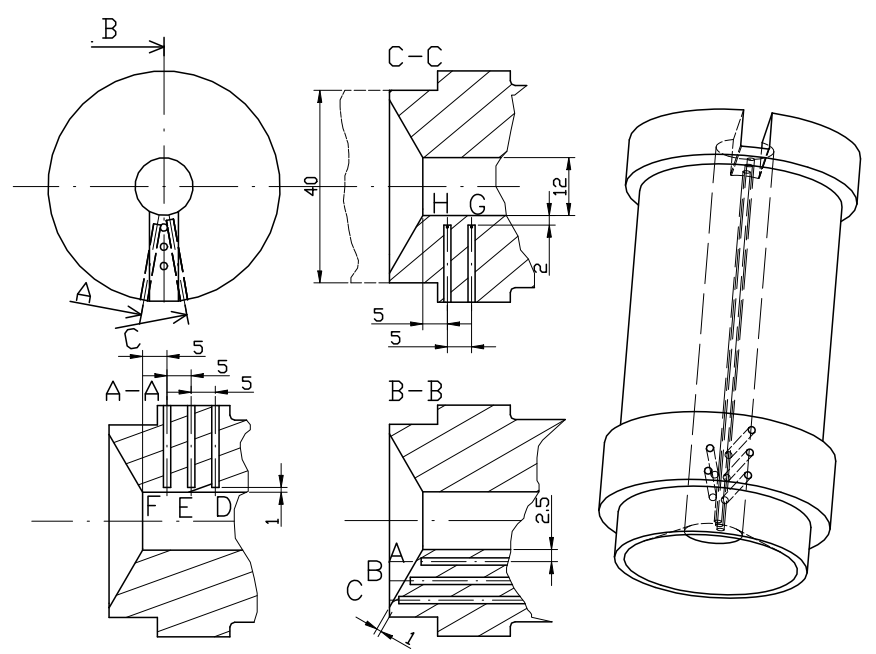

Fig. 2. Thermal sensors positions

The upper die stop is not instantaneous because of the inertia, then the metal is still being deformed while the speed decreases $\left(\mathrm{v}_{\mathrm{MAX}}=1 \mathrm{~m} / \mathrm{s}\right)$. In order to avoid this phenomenon, a shock absorption system (damper) has been placed into the tool. The figure 2 shows the setting used during the tests. This tool is instrumented with load and displacement sensors.

Slug and heating process

Only works about C38 steel (table 1) are discussed in this study. Works of Carole Rouff [7] and Pierre Cézard [9] show that the induction heating of rolled steels allows its forming by thixoforging.

Table1. Chemical composition from C38 (10-3\%) Steel

\begin{tabular}{llllllllll}
$\mathbf{C}$ & $\mathbf{M n}$ & $\mathbf{P}$ & $\mathbf{S}$ & $\mathbf{S i}$ & $\mathbf{A l}$ & $\mathbf{N}$ & $\mathbf{N i}$ & $\mathbf{C r}$ & $\mathbf{C u}$ \\
\hline 418 & 751 & 10 & 21 & 198 & 21 & 65 & 77 & 144 & 133 \\
\hline
\end{tabular}

The choice of a steel grade for its semi-solid forming is essential. Indeed, it determines the temperature of forming and its ability to be formed at semi-solid state.

\section{Parameters affecting the forming process}

A number of tests have been done on C38 steel, the results show that the forming speed, the slug temperature and the die temperature have a major influence on the flow type of steel and the load. Table 2 illustrates the influence of these parameters $[6,10]$. 
Table2. Influence of speed, slug temperature and die temperature on steel thixoforging characteristics

\begin{tabular}{|c|c|c|c|c|c|}
\hline & $\begin{array}{c}\text { Die } \\
\text { speed. } \\
{[\mathrm{mm} / \mathrm{s}]}\end{array}$ & \begin{tabular}{|c} 
Die \\
Temp. $\left[{ }^{\circ} \mathrm{C}\right]$
\end{tabular} & $\begin{array}{c}\text { Slug } \\
\text { Temp }\left[{ }^{\circ} \mathrm{C}\right]\end{array}$ & $\begin{array}{l}\text { Load } \\
{[\mathrm{kN}]}\end{array}$ & Flow \\
\hline \multirow{2}{*}{ Dֶّ̆ } & 40 & \multirow{2}{*}{ Cold } & \multirow{2}{*}{1429} & 320 & $\begin{array}{c}1 \\
\text { Good }\end{array}$ \\
\hline & 200 & & & 190 & $\begin{array}{c}2 \\
\text { Good }\end{array}$ \\
\hline \multirow{3}{*}{ 此䒿 } & \multirow{3}{*}{200} & \multirow{3}{*}{ Cold } & 1450 & 85 & $\begin{array}{c}3 \\
\text { Bad } \\
\end{array}$ \\
\hline & & & 1445 & 135 & $\begin{array}{c}4 \\
\text { Bad } \\
\end{array}$ \\
\hline & & & 1429 & 190 & $\begin{array}{c}5 \\
\text { Good }\end{array}$ \\
\hline \multirow{2}{*}{ 浔 } & \multirow[b]{2}{*}{200} & Cold & \multirow[b]{2}{*}{1447} & 120 & $\begin{array}{c}6 \\
\text { Bad }\end{array}$ \\
\hline & & Hot & & 90 & $\begin{array}{c}7 \\
\text { Good }\end{array}$ \\
\hline
\end{tabular}

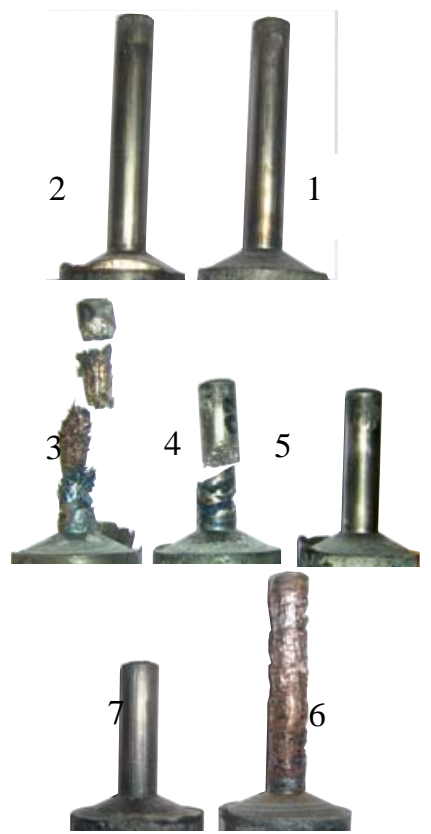

\section{IMPACTS OF THERMAL EXCHANGE}

Heat exchange between the piece and the tools are strongly dependent on the parameters of the process, thus the distribution of the temperatures is variable. Moreover forging time and the speed of deformation affect the change of the temperature within the piece during the forming. These temperature variations generate an evolution of viscosity, disagglomeration, effort of working and consequently of the flow of material and final properties of the part.

Illustration of thermal exchange by a numerical approach

For instance, figure 3 illustrates the influence of extrusion speed on the thermal exchange from numerical simulations with FORGE 2005® software, the other parameters being constant.

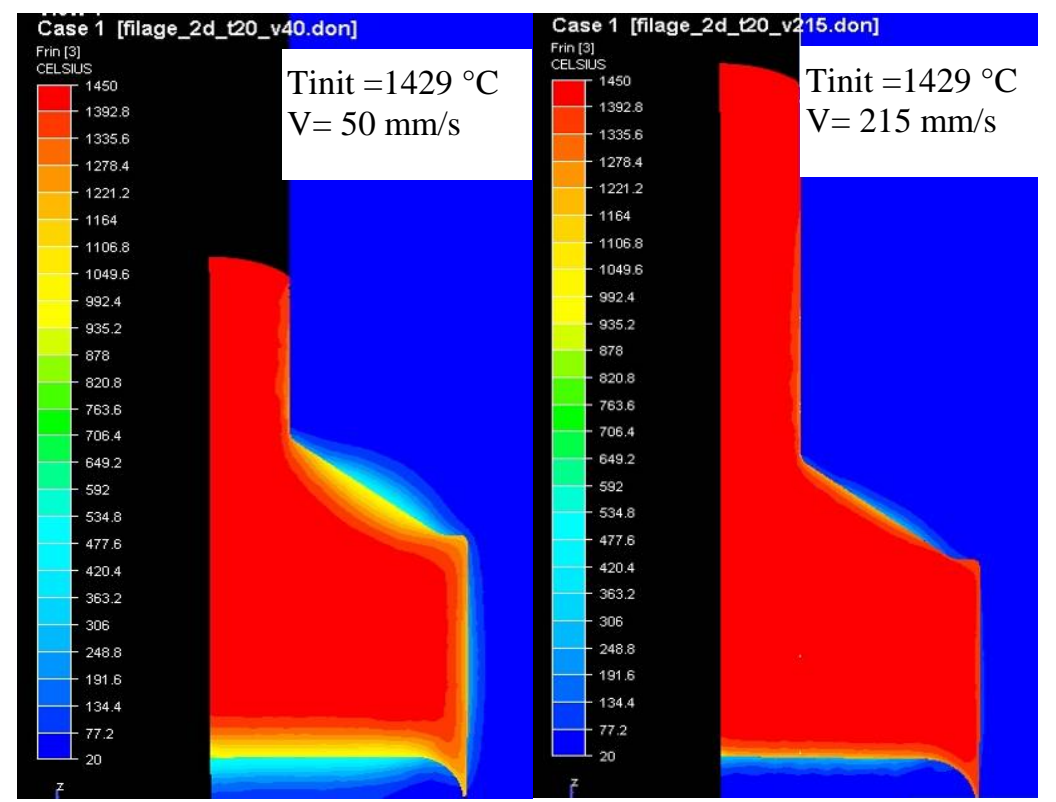

Fig. 3. Temperature distribution in test for two speed (thermal exchange coefficient $20 \mathrm{~kW} / \mathrm{m}$ 


\section{Thermal analysis with experimental approach}

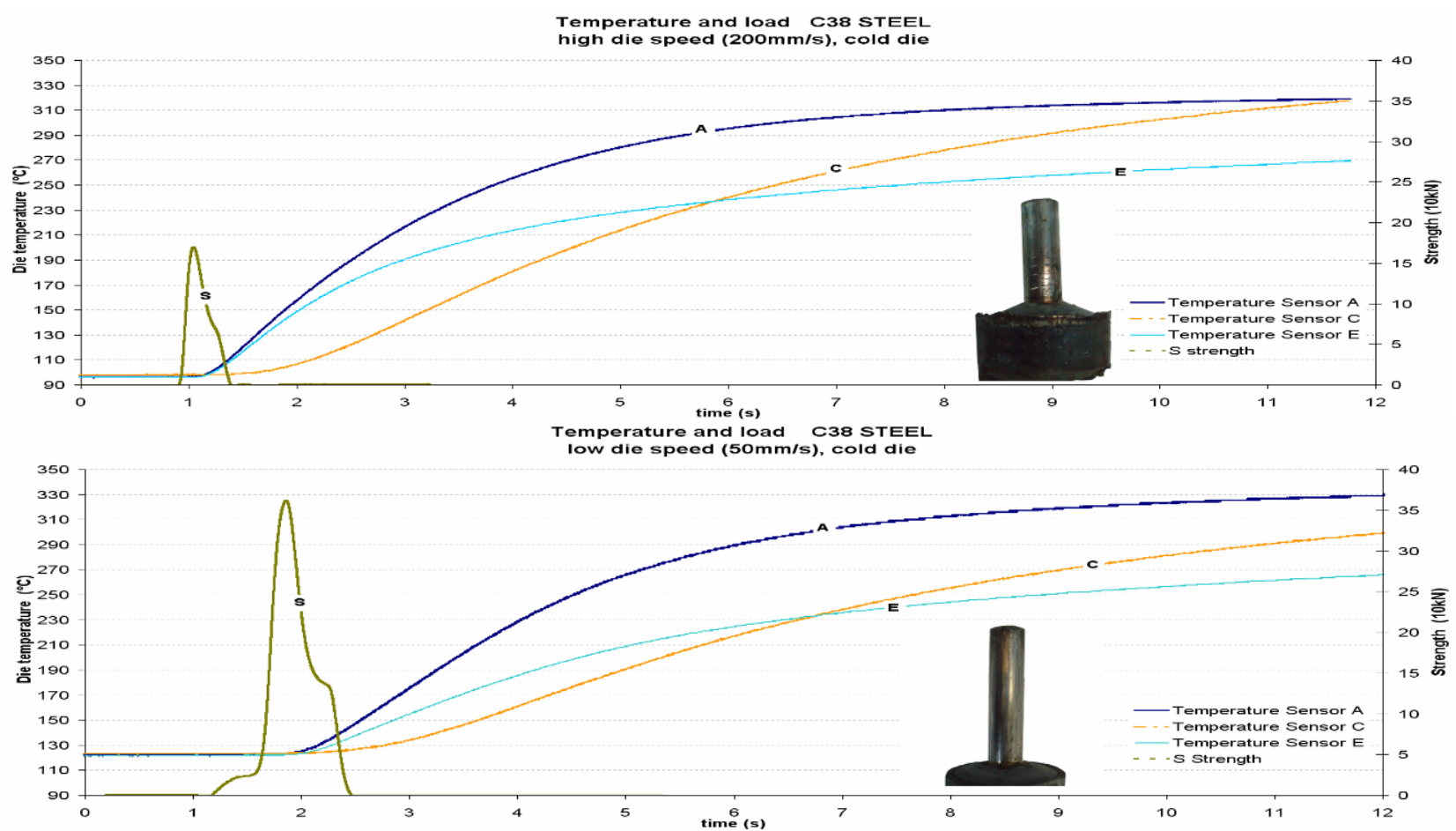

Fig. 4. Shows thermal evolution during thixoforging process versus time

Only three curves representing the change of the temperature in the tool are represented, those of the thermocouples A, E and C. An additional curve represents the load evolution during the process. Global evolution is quite the same for the two tests.

In the case of high speed forming, the temperature are higher. The temperature indicated, after 12 seconds, is lower for the sensor $\mathrm{E}$ than for sensor A. This fact confirms the impact of thermal inertia. Heat thermal exchange is very important at points A and E, so material solidification can happen in the front of the part during extrusion test.

\section{Macroscopic analysis of the thermal affected zone.}

Macrographs 8 and 9 of figure 5 are obtained with extreme conditions (minimal or maximal speed, initial slug temperature, die temperature) in order to get different thermal exchanges. It's possible to distinguish three areas on each sample.

For the extrusion specimen 8 in high thermal exchange conditions, area A illustrates a weak flow rate; the material stays in contact with the dies and is cooled quickly. A part of the metal is wrapped by the area B and C of the slug and enter then in the cone. During the forming process, area B contains a amount of semi-solid metal that is useful to feed the whole shape. Area $\mathrm{C}$ illustrates the axial flow, similar to traditional forging process.

For the extrusion specimen 9 in low thermal exchange conditions, area D is identical to area A, except its thickness is lower. Metal from area E forms waves during the yield, material is semi-solid during the whole forming process. Area F illustrates an axial flow on a part of the extruded area.

The different thickness, of sample 8 and 9, between area A and D corresponds to a much more important and deeper solidification due to a high level of thermal exchange between die and slug, also visible on figure 2. Some high thermal exchanges exist too in area $\mathrm{F}$ and at the end of area $\mathrm{C}$, they explain this typical forging yield. Then, a high gradient is created between the inside and outside of the part, leading to a semi-solid heart during the whole forming process. Area E keeps its semi-solid properties thanks to the areas $\mathrm{D}$ and $\mathrm{F}$, being the thermal shields by limiting the heat transfer with the die.

Sample 10 has three zones of distinct flows. Zone I illustrates a flow similar to the zones $\mathrm{F}$ and C. 


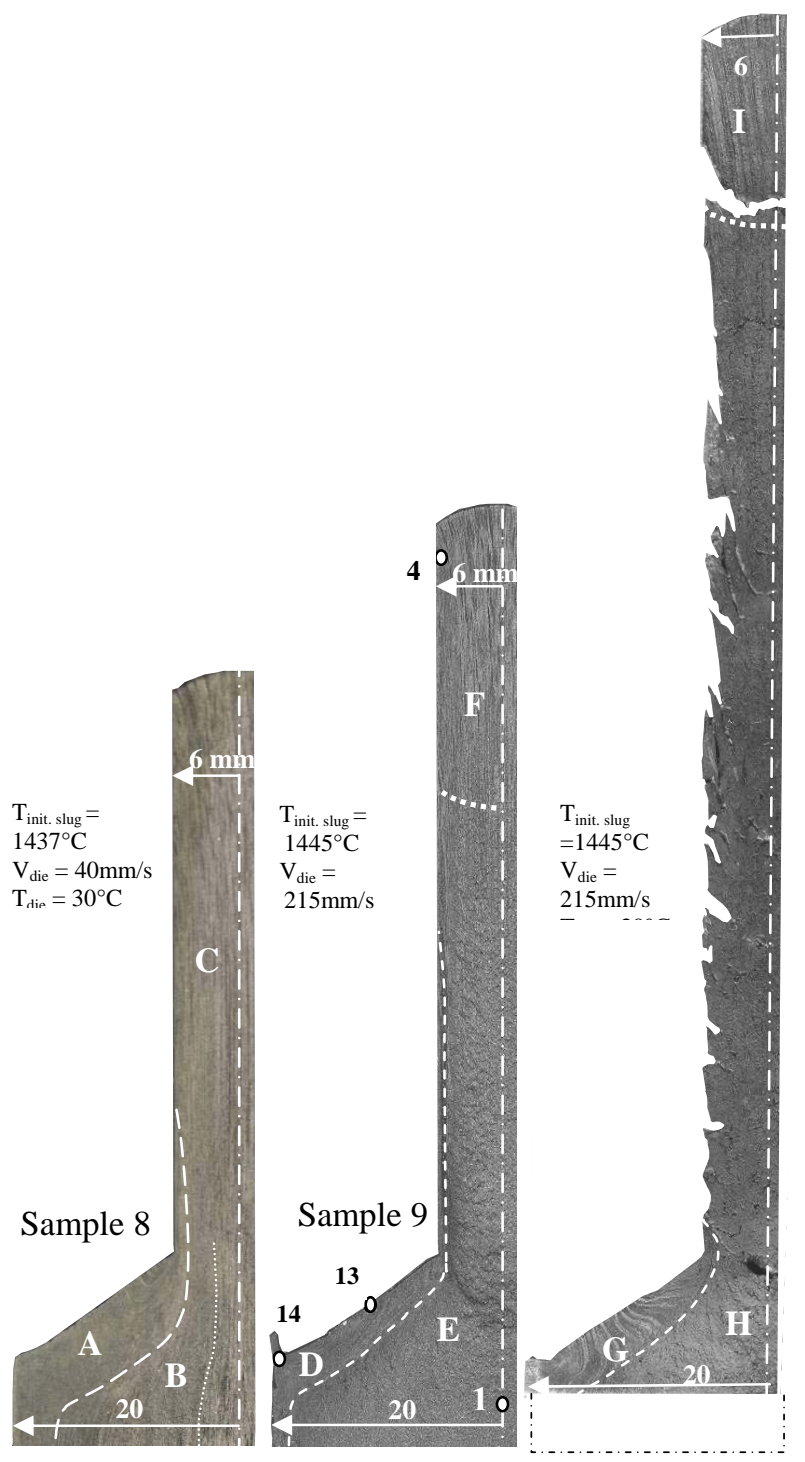

Fig. 5. Macrostructures displaying the flow of semisolid C38 steel for different heat flux conditions between the die and the material
Table3. Microstructures show the impact from forming

\begin{tabular}{|c|c|c|}
\hline Points & $\begin{array}{ll}\text { Testpiece } 9 & \mathrm{~T}_{\text {slug }}=1437^{\circ} \mathrm{C} \\
\mathrm{T}_{\text {die }}=30^{\circ} \mathrm{C} & \mathrm{V}_{\text {die }}=40 \mathrm{~mm} / \mathrm{s}\end{array}$ & $\begin{array}{ll}\text { Testpiece 10 } & \mathrm{T}_{\text {slug }}=1437^{\circ} \mathrm{C} \\
\mathrm{T}_{\text {die }}=30^{\circ} \mathrm{C} & \mathrm{V}_{\text {die }}=215 \mathrm{~mm} / \mathrm{s}\end{array}$ \\
\hline 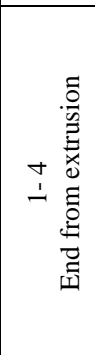 & $\begin{array}{l}\text { Structure consists of envelopes } \\
\text { of proeutectoid ferrite (light) } \\
\text { with emerging spines of ferrite, } \\
\text { in a matrix of pearlite (grey) } \\
\text { ([11] fig. 132 page 188). } \\
\text { HV=237 }\end{array}$ & $\begin{array}{l}\quad \text { 100um } \\
\text { Ferrite (light) at prior austenite } \\
\text { grain boundaries and plates } \\
\text { within grains in a matrix of } \\
\text { pearlite (grey) ([11] fig. } 19 \\
\text { page 213) HV=255 }\end{array}$ \\
\hline 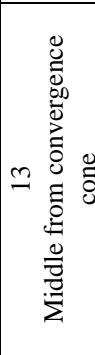 & $\begin{array}{l}\text { Surface shows decarburization. } \\
\text { The light areas near bottom of } \\
\text { micrograph are ferrite; the } \\
\text { matrix is pearlite (grey) ([11] } \\
\text { fig. 18 page 213) } \mathrm{HV}=173\end{array}$ & $\begin{array}{l}\text { Ferrite (light) at prior austenite } \\
\text { grain boundaries and plates } \\
\text { within grains in a matrix of } \\
\text { pearlite (grey ([11] fig. } 19 \text { page } \\
\text { 213) HV=201 }\end{array}$ \\
\hline 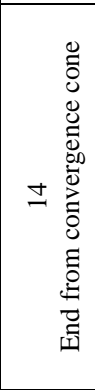 & $\begin{array}{l}\text { Surface shows clearly } \\
\text { decarburization. The light areas } \\
\text { near bottom of micrograph are } \\
\text { ferrite; the matrix is pearlite } \\
\text { ([11] fig. 18 page 213) } \\
\text { HV=179 }\end{array}$ & $\begin{array}{l}\text { Dete absence of } \\
\text { decarburization. Ferrite at grain } \\
\text { boundaries and as plates in } \\
\text { pearlite grains([11] fig. } 17 \\
\text { page 213) HV=184 }\end{array}$ \\
\hline 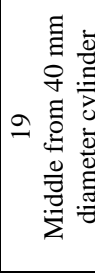 & $\begin{array}{l}\text { Ferrite (light) within in a } \\
\text { matrix of pearlite (grey) ([11] } \\
\text { fig. } 20 \text { page 213) }\end{array}$ & \begin{tabular}{l}
\multicolumn{1}{c}{100 um } \\
Ferrite (light) within in a \\
matrix of pearlite (grey) ([11] \\
fig. 20 page 213)
\end{tabular} \\
\hline
\end{tabular}

\section{Impact of thermal exchanges on local mechanical properties}

\section{Hardness and micrographs}

Extruded part hardness is analysed by Vickers hardness tests under a 3kg load. Figure 6 shows a summary of experimental hardness results. Table 3 illustrates micrographs associated with specimens 9 and 10 of figure 6 . We used the Handbook reference [11] to analyse these micrographs. Indeed, the micrographs are very similar despite the fact that the experimental conditions used to obtain our micrographs are different from the conditions used in [11].

The Vickers hardness reduction at the points 13 and 14 illustrates a low cooling speed after the forming (the cooling is made into the dies) or a chemical gradient of the slug. Micrographs confirm by high ferrite grade of decarburized area, that it is not very sensitive to the cooling speed.

The variation of the Vickers hardness is less important when the forming speed is higher. Figure 6 compares hardness of parts forged with heated dies $\left(400^{\circ} \mathrm{C}\right)$ and those with room temperature dies. Vickers hardness is less important when the dies are heated; there is thus less thermal exchange between slug and die. Points 13 and 14 have the lowest hardness, microstructures show a decarburized area already observed before. Point 19, at the heart of the sample, has an important grain size, independent from the tool temperature. This point is maintained at high temperature for a long time during the forming process. 


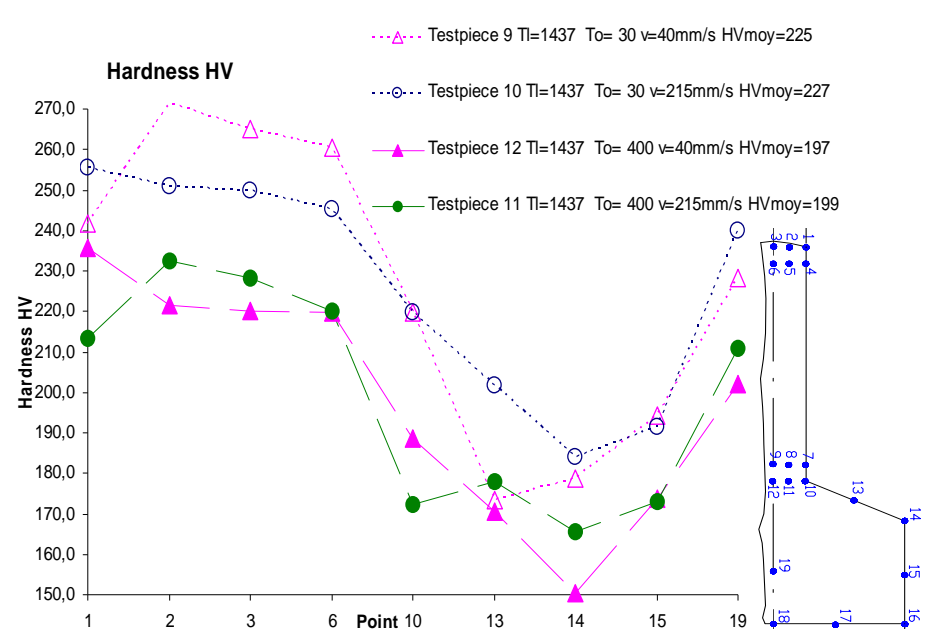

Table4. Influence of different thixoforging parameters on C38 steel mechanical characteristic

\begin{tabular}{|c|c|c|c|c|c|}
\hline $\begin{array}{c}\text { Speed } \\
{[\mathrm{mm} / \mathrm{s}]}\end{array}$ & $\begin{array}{l}\mathrm{T}^{\circ}{ }_{\text {die }} / \mathrm{T}^{\circ}{ }_{\mathrm{sl}} \\
{\left[{ }^{\circ} \mathrm{C}\right]}\end{array}$ & $\begin{array}{c}\mathrm{Rp} 0,2^{*} \\
{\left[\mathrm{~N} / \mathrm{mm}^{2}\right]}\end{array}$ & $\begin{array}{c}\mathrm{Rm}^{*} \\
{\left[\mathrm{~N} / \mathrm{mm}^{2}\right]}\end{array}$ & $\mathrm{Rp} / \mathrm{Rm}$ & $\mathrm{A} \%$ \\
\hline 50 & $\mathbf{3 0 / 1 4 2 0}$ & 537 & $\mathbf{8 1 8}$ & 0,66 & 18,9 \\
\hline 50 & $\mathbf{4 0 0 / 1 4 2 9}$ & $\mathbf{4 5 7}$ & 756 & 0,60 & $\mathbf{2 1 , 0}$ \\
\hline $\mathbf{2 0 0}$ & $\mathbf{3 0 / 1 4 2 0}$ & 504 & 800 & 0,63 & 20,7 \\
\hline $\mathbf{2 0 0}$ & $\mathbf{4 0 0 / 1 4 2 9}$ & $\mathbf{4 5 8}$ & 765 & 0,60 & $\mathbf{1 6 , 0}$ \\
\hline \multicolumn{2}{|c|}{$\begin{array}{l}\text { Steel data } \\
\text { from C38 }\end{array}$} & $\mathbf{2 4 3 0}$ & $\begin{array}{c}650 \text { to } \\
800\end{array}$ & & $\geq \mathbf{1 6}$ \\
\hline
\end{tabular}

Fig. 6. Vickers Hardness (weight $3 \mathrm{~kg}$, steel C38, $\mathrm{T}_{\text {slug }}=1437^{\circ} \mathrm{C}$ )

\section{Elasticity, strength and elongation}

Elasticity limit, strength and elongation are determined by tensile tests. Table 4 shows a synthesis of the results obtained on groups of three specimens sampled among thixoforged extruded parts in different conditions of speed, die temperature and slug temperature.

Elasticity limit and strength are quite constant while forming speed varies (max. 6\% for Rp and max. 2,3\% for $\mathrm{Rm}$ ), though they decrease when die temperature increases (min. 10\% for Rp and min. 4,4\% for Rm),which is normal for a high variation of the thermal gradient (die - part) during the forming process and for high temperature level for heated dies.

Elongation increases when $\mathrm{Rm}$ and $\mathrm{Rp}$ decrease, which is normal too except for the last values $\left(v=200 \mathrm{~mm} / \mathrm{s}\right.$ and $\left.\mathrm{To}=400^{\circ} \mathrm{C}\right)$. Characteristics are the same as the native state of the steel.

\section{CONCLUSIONS}

This work confirms the existence of a complex flow during forming of steel in a semi-solid state. Important heat exchanges are at the origin of a partial solidification (traditional forging) visualized on each macrograph. This heterogeneity leads naturally to heterogeneity of microstructures and Vickers pyramid hardness towards the axis of samples.

This work combined with the previous researches confirms that tool design with closed dies for thixoforging is quite similar to net-shape forging. From a forged product point of view, experimental results lead to a new design of parts from functional specifications. This design approach is based on predictive tools such as behaviour laws developed and implemented with dedicated software such as Forge2005® $[9,12]$.

\section{REFERENCES}

1. Chiarmetta, G., Thixoformage et gain de poids : application industrielle du formage à l'état semi-solide. Hommes et Fonderie, 2000(302): p. 2934.

2. Chiarmetta, G., Thixoforming of automobile components. Proceeding of the 4th international conference on semi-solid processing of alloys and composites, Sheffield, 1996: p. 204-207.

3. Suery, M., Mise en forme des alliages métalliques à l'état semi-solide. Lavoisier, Hermes Sciences, 2002. Traité MIM.

4. Atkinson, H.V., Modelling the semisolid processing of metallic alloys. Progress in Materials Science, 2005. 50(3): p. 341-412.

5. Bigot, R., V. Favier, and C. Rouff, Characterization of semi-solid material mechanical behavior by indentation test. Journal of Materials Processing Technology, 2005. 160: p. 43-53.

6. Cezard, P., et al. Thixoforming of Steel: New tools conception to analyse thermal exchanges and strain rate effects. in ESAFORM 2007. 2007, April 18th-20th. Saragossa, Spain.

7. Rouff, C., Contribution à la caractérisation et à la modélisation du comportement d'un acier à l'état semi-solide. Application au thixoforgeage. 2003, ENSAM: Metz.

8. Favier, V., et al., Micro-macro modelling of the isothermal steady-state behaviour of semi-solids. International Journal of Forming Processes, 2004. 7: p. 177-194.

9. Cezard, P., Impact des effets thermiques sur le comportement du matériau lors de la mise en forme des aciers à l'état semi-solide : analyse expérimentale et numérique, Ph.D. thesis in ENSAM Metz. 2006.

10. Becker, E., et al. Influence de la vitesse de mise en forme et du cycle sur le thixoforgeage des aciers. in HSIMP. 2007, November 13th-14th. Senlis, France.

11. Handbook, A., Metallography and Microstuctures, ed. M.H. Formerly Ninth Edition. Vol. 9. 1998.

12. Cezard, P., et al., Simulation of semi-solid thixoforging using a micromacro constitutive equation. Computational Materials Science, 2005. 32: p. 323-328. 